The cardiac rhythm was regular in all cases. The first mitral sound was split in 2 cases, and the intensity of this sound was diminished in 10 others, compatible with their age and varying degrees of emphysema ; otherwise no abnormality was noted. However, it would be only in the incidence and character of murmurs indicative of valvular disease that a parallel between this disease and rheumatic fever could be drawn. A particularly careful search was made for evidence of early mitral stenosis, but none was found. In 8 cases a faint systolic murmur was heard at the mitral area ; in all of these it was sharply localized. None of them was associated with a loud sharp first sound or with an accentuated second pulmonary sound. They were considered to be functional in origin. In one case only was there a loud mitral systolic murmur; it did not replace the first sound but was conducted well into the axilla. This occurred in a woman of 68 who had had rheumatoid arthritis for nine years, and the signs were thought to indicate organic mitral valve disease.

\section{Electrocardiographic Findings}

There are, of course, no electrocardiographic abnormalities pathognomonic of rheumatic fever; the study of electrocardiograms in rheumatoid arthritis is therefore of limited value in studying the aetiological relationship between the two diseases. According to Katz (1941) chronic rheumatic heart disease may result in tracings showing preponderance of one or other ventricle resulting from valve deformities, or the appearance of large, broad, or notched $P$ waves associated with auricular hypertrophy. Specific contour changes and arrhythmias may develop, such as frequent auricular premature beats, which are said to be particularly significant when they arise from multiple foci. Electrocardiograms were taken from 29 patients. Left axis shift was present in 17 ; there was a considerable incidence of slurring of the QRS complexes, and the $T$ wave was inverted in one case in Lead $I$, in another in Lead II, and in a third in Lead $\mathrm{CF}_{4}$. These abnormalities were consistent with the senile degeneration of the coronary arteries of old people, who formed the majority of the patients in this series. None of the records showed abnormal ventricular preponderance, the $\mathbf{P}$ waves were well formed, and the cardiac rhythm was unaffected. A woman of 71 , who gave a history of only three months' illness but who had obvious joint changes on $x$-ray examination, showed very low complexes in all leads when the first electrocardiogram was taken. Serial tracings showed an increasing amplitude of the complexes until five weeks later the voltage was well within normal limits. This suggests that there was transient myocardial damage during the acute phase of the illness, but it does not necessarily denote any common aetiological factor between rheumatoid arthritis and rheumatic fever; such findings might be encountered in many acute illnesses and toxic states.

Only one patient in the present series came to necropsy. She was an elderly woman who died of cerebral thrombosis. The naked-eye appearances and histological findings in the heart revealed no evidence of rheumatic infection.

\section{Discussion}

The results of this investigation serve to emphasize once again the extraordinary discrepancies which exist in the opinions of different workers. No doubt this is largely the result of failure to lay down generally acceptable criteria for the clinical diagnosis of cardiac lesions in the early stages of disease. Another difficulty is that of excluding cardiac abnormalities which are purely incidental and usually the accompaniments of senile degenerative changes in the myocardium and coronary arteries. After making liberal allowances for these complicating factors, it would appear that clinical evidence of mitral valve disease was elicited in only one patient in a series of 33 cases of rheumatoid arthritis. The literature cited raises the possibility that the incidence of subclinical valvular disease associated with rheumatoid arthritis in the present group was much higher than this, but in the solitary case examined at necropsy no cardiac abnormalities were detected. A final opinion on the concept of latent or subclinical endocarditis must await further pathological studies, which will need to be sufficiently comprehensive; the difficulties in the way of obtaining these data in a disease which per se is rarely fatal need no emphasis.

\section{Summary}

Recent literature on the subject of the aetiological relationships between rheumatic fever and rheumatoid arthritis is reviewed.

Among 33 patients suffering from rheumatoid arthritis only one was found to have a cardiac lesion which might have been attributable to the disease. Another patient came to necropsy, and was found to have neither histological nor naked-eye abnormalities of the heart.

A brief reference is made to the limited value of comparisons between the clinical manifestations of these two conditions in the present state of our knowledge of the rheumatic diseases.

I have pleasure in expressing my indebtedness to Prof. Noah Morris and Dr. Stanley Alstead, who assisted me in the preparation of this paper. My thanks are also due to Drs. Briggs and Cunningham, medical superintendents of Stobhill Hospital and the Eastern District Hospital, respectively, for permission to publish.

REFERENCES

Baggenstoss, A. H., and Rosenberg, E. F. (1941). Arch. intern. Med., 67, 241. (1944). Arch. Path., 37, 54.

B. (1943). Amer. J. med. Sci. 205, 42

Bennett, G. A., Zeller, J. W., and Bauer, W. (1940), Arch. Path., 30, 70.

Collins, D. H. (1937), J, Path. Bact. 45, 97.

Dawson, M. H., and Tyson, T. L. (1936). J. Lab. clin. Med., 21, 575.

Fraser T. N (1945). Ann. rheum. Dis 4, 71.

(1941) Clinical Electrocardiography,

(1932).J.Amer. med Ass, 98, 881 .

Sclater, J. G. (1943). Ann. rheum. Dis., 3, 195.

White, P. D. (1944). 'Heart Disease, New York.

Young, D., and Schwedel, J. B. (1944). Amer. Heart J., 28, 1.

\section{}

\section{INCIDENCE OF YAWS AND OF VENEREAL DISEASES IN LANGO (UGANDA)}

BY

\section{J. HACKETT, M.D.}

Director, Wellcome Museum of Medical Science, London

During a study of the bone lesions of yaws in Lango the high incidence of that disease became apparent. Since a medical survey was not practical, nor was it necessitated by trypanosomiasis, other measures were sought to ascertain more precisely the frequency of yaws. At the same time the incidence of venereal diseases in Lango and, for comparison, in Ganda was assessed. Medical reports were examined, out-patient attendance records analysed, and a labour force and a sample of a gaol population were studied. These data form the basis of this paper.

The results of a survey for leprosy are contained in the annual report of the District Medical Officer of Lango for 1931. Of 24,249 children under 15 years of age, $963(3.9 \%)$ were suffering from secondary yaws. Of 152 cases of secondary yaws with bone lesions studied by me in 1937-9, $131(86 \%)$ were under 10 years of age. Active secondary yaws in children was observed in practically every Lango community, and chiefs frequently stressed its high incidence. The absence of yaws in infants before the age of walking was also noted.

\section{Survey of Out-patient Attendances, Lira and Masaka}

Lira (Lango district), about $3,600 \mathrm{ft}$. $(1,100 \mathrm{~m}$.) above sea level and.north of Kampala, is in a part of Uganda described as a "yaws area"-i.e., one in which yaws is common and syphilis rarely occurs. Masaka (Ganda Province), about 4,300 ft. $(1,300 \mathrm{~m}$.) above sea level and south-west of Kampala, is in a part regarded as a "syphilis area " and in which yaws is infrequent. This characteristic local distribution of the two diseases applies only to the indigenes. Masaka has been chosen rather than Kampala for comparison with Lira, since it is not so large a centre as Kampala, and data from it are thus more likely to give an accurate picture of the conditions present in a rural community. The figures in Tables I, II, and IV were obtained from the monthly sick returns for Lira and Masaka, which were based mainly upon the diagnoses of trained African medical orderlies. Their diagnoses of the conditions concerned may be regarded as fairly accurate. Orderlies with experience in both syphilis and yaws areas were working in both clinics. 
TABLE I.-Average Annual Out-patient Attendances by New Cases at Lira and Masaka for the More Frequent Complaints (excluding Coughs, Colds, and Traumatic Lesions). and for Syphilis and Gonorrhoea

\begin{tabular}{|c|c|c|c|c|c|c|c|}
\hline & & & & \multicolumn{2}{|c|}{ Lira (1928-36) } & \multicolumn{2}{|c|}{ Masaka (1930-8) } \\
\hline & & & & Totals & $\%$ & Totals & $\%$ \\
\hline $\begin{array}{l}\text { Yaws .. } \\
\text { Syphilis . } \\
\text { Gonorrhoea } \\
\text { "Myalgia " } \\
\text { Ulcers . } \\
\text { Malaria .. }\end{array}$ & $\begin{array}{l}\cdots \\
\cdots \\
\cdots \\
\cdots \\
\cdots\end{array}$ & $\begin{array}{l}\cdots \\
\ldots \\
\cdots \\
\cdots\end{array}$ & $\begin{array}{l}\ldots \\
\ldots \\
\cdots \\
\ldots \\
.\end{array}$ & $\begin{array}{r}3,077 \\
164 \\
85 \\
662 \\
803 \\
775 \\
\end{array}$ & $\begin{array}{r}20 \cdot 9 \\
1 \cdot 1 \\
0.6 \\
4 \cdot 5 \\
5 \cdot 5 \\
5 \cdot 3\end{array}$ & $\begin{array}{r}266 \\
2,818 \\
410 \\
340 \\
443 \\
1,966 \\
\end{array}$ & $\begin{array}{r}1.6 \\
17.5 \\
2.5 \\
2.1 \\
2.8 \\
12.1\end{array}$ \\
\hline \multicolumn{4}{|c|}{ Ratio of gonorrhoea to syphilis } & \multicolumn{2}{|c|}{0.5 to 1} & \multicolumn{2}{|c|}{0.15 to 1} \\
\hline \multicolumn{4}{|c|}{ Total attendances (all causes) } & \multicolumn{2}{|c|}{14,707} & \multicolumn{2}{|c|}{16,207} \\
\hline
\end{tabular}

The incidence of yaws at Lira was 13 times that at Masaka, while the incidence of syphilis in Masaka was 16 times that at Lira. At Lira the incidence of yaws was 19 times that of syphilis, and at Masaka syphilis was 11 times more prevalent than yaws. Congenital syphilitic infants were frequent at Masaka. Gonorrhoea, however, was only 4 times more frequent at Masaka than at Lira. The proportion of new cases of gonorrhoea to those of syphilis at Lira was 0.5 to 1 , and at Masaka 0.15 to 1 . This ratio in England and Wales in 1936 was 2.6 to 1 (18th Annual Report of the Ministry of Health). The figures for gonorrhoea at Masaka may be incomplete, since in Ganda Province this disease is prevalent. It is unfortunate that the incidence of gonorrhoea cannot be used as a check on that of syphilis. At Lira "myalgia" and "ulcers" were diagnosed twice as frequently as at Masaka. Malaria was only about half as frequently diagnosed at the former as at the latter, but at both the real incidence probably appreximated to $80-100 \%$.

The Medical Officer at Masaka (Dr. A. G. Mackay) said that most of the yaws cases seen there were in immigrant labourers from the Belgian mandated territory of Ruandi-Urundi, and that the disease was rarely seen in the indigenous Ganda population. At Lira the Medical Officer's annual reports repeatedly state that most cases of syphilis and gonorrhoea occurred in Bantu immigrants (Ganda and Nyoro) and in Kumam people, and very infrequently in the indigenous Lango. Personal observations confirmed this. At Lira, though the total attend-

TABLE II.-Sex Distributions of Average Annual Out-patient Attendances for All Causes, and for Yaws and for Syphilis, at Lira and Masaka

\begin{tabular}{|c|c|c|c|c|c|c|c|}
\hline & \multirow[b]{2}{*}{. } & \multicolumn{3}{|c|}{ Lira (1928-36) } & \multicolumn{3}{|c|}{ Masaka (1930-8) } \\
\hline & & Totals & $\begin{array}{l}\% \text { of } \\
\text { Totals }\end{array}$ & $\begin{array}{l}\% \text { of } \\
\text { Totals } \\
\text { for Sex }\end{array}$ & Totals & $\begin{array}{l}\% \text { of } \\
\text { Totals }\end{array}$ & $\begin{array}{c}\% \text { of } \\
\text { Totals } \\
\text { for Sex }\end{array}$ \\
\hline All cases & $\left\{\begin{array}{l}\text { Total } \\
\text { Males } \\
\text { Females }\end{array}\right.$ & $\begin{array}{r}14,707 \\
9,755 \\
4,952\end{array}$ & $\begin{array}{l}66 \cdot 0 \\
34 \cdot 0\end{array}$ & & $\begin{array}{r}16,207 \\
10,008 \\
6,199\end{array}$ & $\begin{array}{l}61 \cdot 0 \\
39 \cdot 0\end{array}$ & \\
\hline Yaws & $\left\{\begin{array}{l}\text { Total } \\
\text { Males } \\
\text { Females }\end{array}\right.$ & $\begin{array}{l}3,077 \\
1,599 \\
1,478\end{array}$ & $\begin{array}{l}52 \cdot 0 \\
48 \cdot 0\end{array}$ & $\begin{array}{l}16 \cdot 3 \\
29 \cdot 8\end{array}$ & $\begin{array}{r}266 \\
187 \\
79\end{array}$ & $\begin{array}{l}70 \cdot 0 \\
30 \cdot 0\end{array}$ & $\begin{array}{l}1.87 \\
1.27\end{array}$ \\
\hline Syphilis & $\left\{\begin{array}{l}\text { Total } \\
\text { Males } \\
\text { Females }\end{array}\right.$ & $\begin{array}{r}164 \\
95 \\
69\end{array}$ & $\begin{array}{l}58 \cdot 0 \\
42 \cdot 0\end{array}$ & $\begin{array}{l}0.98 \\
1.39\end{array}$ & $\begin{array}{l}2,818 \\
1,567 \\
1,251\end{array}$ & $\begin{array}{l}55.0 \\
45.0\end{array}$ & $\begin{array}{l}15 \cdot 7 \\
20 \cdot 2\end{array}$ \\
\hline
\end{tabular}

ance by females was only half of that by males, the attendance for yaws by females was nearly equal to that by males. At Masaka the total attendance by females was $60 \%$ of that by males, and the attendance for syphilis by females was $80 \%$ of that by males. The attendances for both diseases included cases at all ages and all stages. The higher attendance by females for yaws at Lira may in part result from mothers accompanying their yaws-infected children to the clinic and presenting themselves for treatment for late yaws lesions. The higher female attendance for syphilis at Masaka may partly arise from women being more alert regarding early secondary skin lesions.

The figures in Table III were obtained by the then Director of Medical Services of Uganda (Dr. W. H. Kauntze). It will be seen that at Lira the yaws cases were a random sample of all other attendances. At Masaka fewer children attended the out-patient department than at Lira; the smaller number of
TABLE III.-Sex and Age Distribution of Out-patient Attendances by New Cases for Yaws at Lira and Syphilis at Masaka (A pril, 1940)

\begin{tabular}{|c|c|c|c|c|c|c|c|}
\hline & & \multicolumn{3}{|c|}{ Lira } & \multicolumn{3}{|c|}{ Masaka } \\
\hline & & $\begin{array}{l}\text { Under } \\
10 \text { yrs. }\end{array}$ & $\begin{array}{c}\text { Over } \\
10 \text { yrs. }\end{array}$ & Total & $\begin{array}{l}\text { Under } \\
10 \text { yrs. }\end{array}$ & $\begin{array}{c}\text { Over } \\
10 \text { yrs. }\end{array}$ & Total \\
\hline & & All & ases less & & All C & ses less $S$ & hilis \\
\hline \multirow[t]{2}{*}{$\begin{array}{l}\text { Males } \\
\text { Females } \\
\text { Total }\end{array}$} & $\begin{array}{l}\ldots \\
\cdots\end{array}$ & $\begin{array}{c}141 \\
123 \\
264 \\
(22 \cdot 5 \%)\end{array}$ & $\begin{array}{l}624 \\
284 \\
908\end{array}$ & $\begin{array}{r}765 \\
407 \\
1,172\end{array}$ & $\begin{array}{c}121 \\
103 \\
224 \\
(16 \cdot 1 \%)\end{array}$ & $\begin{array}{r}829 \\
340 \\
1,169\end{array}$ & $\begin{array}{r}950 \\
443 \\
1,393\end{array}$ \\
\hline & & \multicolumn{3}{|c|}{ Yaws } & \multicolumn{3}{|c|}{ Syphilis } \\
\hline $\begin{array}{l}\text { Males } \\
\text { Females } \\
\text { Tota! }\end{array}$ & $\begin{array}{l}. \\
\ldots\end{array}$ & $\begin{array}{c}34 \\
33 \\
67 \\
(23 \cdot 8 \%)\end{array}$ & $\begin{array}{l}103 \\
112 \\
215\end{array}$ & $\begin{array}{l}137 \\
145 \\
282\end{array}$ & $\begin{array}{c}6 \\
8 \\
14 \\
(9 \cdot 5 \%)\end{array}$ & $\begin{array}{r}79 \\
55 \\
134\end{array}$ & $\begin{array}{r}85 \\
63 \\
148\end{array}$ \\
\hline
\end{tabular}

TABLE IV.-Average Monthly Out-patient Attendances by New Cases less Yaws and of Yaws at Lira (1928-36)

\begin{tabular}{|c|c|c|c|c|c|c|c|}
\hline Month & & Yaws & $\begin{array}{c}\text { Total } \\
\text { Attendances } \\
\text { less Yaws }\end{array}$ & Month & & Yaws & $\begin{array}{c}\text { Total } \\
\text { Attendances } \\
\text { less Yaws }\end{array}$ \\
\hline $\begin{array}{l}\text { January } \\
\text { February } \\
\text { March .. } \\
\text { April } \quad . \\
\text { May } \quad . \\
\text { June } \quad .\end{array}$ & $\begin{array}{l}\ldots \\
\cdots \\
\cdots \\
\cdots\end{array}$ & $\begin{array}{l}189 \\
243 \\
317 \\
327 \\
279 \\
296\end{array}$ & $\begin{array}{l}936 \\
874 \\
953 \\
951 \\
894 \\
960\end{array}$ & $\begin{array}{l}\text { July . . } \\
\text { August } \\
\text { September } \\
\text { October } \\
\text { November } \\
\text { December }\end{array}$ & $\begin{array}{l}\cdots \\
\cdots \\
\cdots \\
\cdots\end{array}$ & $\begin{array}{l}247 \\
210 \\
232 \\
293 \\
259 \\
185\end{array}$ & $\begin{array}{r}1,017 \\
944 \\
1,000 \\
1,071 \\
1,081 \\
949\end{array}$ \\
\hline
\end{tabular}

Table V.-Average Monthly Climatic Data for Lira (Ngetta), 1928-36. (British East African Meteorological Service)

\begin{tabular}{|c|c|c|c|c|c|c|}
\hline \multirow{2}{*}{ Month } & \multicolumn{3}{|c|}{ Air Temperature $\left({ }^{\circ} \mathrm{F}\right.$ ) } & \multicolumn{2}{|c|}{$\begin{array}{c}\text { Relative } \\
\text { Humidity (\%) }\end{array}$} & \multirow{2}{*}{$\begin{array}{l}\text { Rainfall } \\
\text { (inches) }\end{array}$} \\
\hline & Maximum & Minimum & $\frac{\text { Max. }+ \text { Min. }}{2}$ & $08 \cdot 30$ & $14 \cdot 30$ & \\
\hline 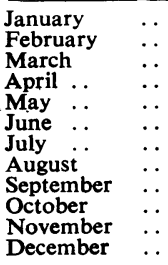 & $\begin{array}{l}91 \cdot 8 \\
92.4 \\
90 \cdot 4 \\
86 \cdot 7 \\
83 \cdot 5 \\
82 \cdot 8 \\
81 \cdot 7 \\
83 \cdot 2 \\
85 \cdot 2 \\
86 \cdot 5 \\
86 \cdot 5 \\
87 \cdot 7\end{array}$ & $\begin{array}{l}60 \cdot 4 \\
63 \cdot 6 \\
64 \cdot 6 \\
64 \cdot 1 \\
63 \cdot 8 \\
62 \cdot 4 \\
61 \cdot 7 \\
61 \cdot 5 \\
61.8 \\
61.8 \\
61 \cdot 3 \\
60 \cdot 3\end{array}$ & $\begin{array}{l}76 \cdot 1 \\
78 \cdot 0 \\
77 \cdot 5 \\
75 \cdot 4 \\
73 \cdot 6 \\
72 \cdot 6 \\
71 \cdot 7 \\
72 \cdot 3 \\
73 \cdot 5 \\
74 \cdot 1 \\
74 \cdot 9 \\
74 \cdot 0\end{array}$ & $\begin{array}{l}61 \\
76 \\
77 \\
83 \\
84 \\
84 \\
86 \\
84 \\
82 \\
79 \\
76 \\
72\end{array}$ & $\begin{array}{l}32 \\
40 \\
41 \\
50 \\
59 \\
57 \\
57 \\
58 \\
53 \\
49 . \\
46 \\
42\end{array}$ & $\begin{array}{l}1 \cdot 25 \\
1.40 \\
3 \cdot 29 \\
6 \cdot 72 \\
8 \cdot 55 \\
5 \cdot 32 \\
4 \cdot 18 \\
8 \cdot 49 \\
6 \cdot 30 \\
5.82 \\
2.69 \\
2 \cdot 55\end{array}$ \\
\hline Annual values & $86 \cdot 7$ & $62 \cdot 3$ & $74 \cdot 5$ & 79 & 49 & $56 \cdot 56$ \\
\hline $\begin{array}{l}\text { Annual values } \\
\text { for Masaka, } \\
1928-36\end{array}$ & $79 \cdot 6$ & $61 \cdot 1$ & $70 \cdot 3$ & 84 & 62 & $49 \cdot 41$ \\
\hline
\end{tabular}

children among the syphilis cases compared with those among all other cases is statistically significant $(6.6 \pm 3.12)$. This stresses the higher ages of the syphilis patients.

In Table IV the variations in the average monthly attendances for yaws are statistically significant. The figures for males and females closely resembled those for the sexes combined. The variations in the average monthly attendances for syphilis at Masaka were not statistically significant. It will be seen that the peaks of maximal incidence of yaws were in April and October, and that there were ascending peaks for the total attendances less yaws in March-April, July, and OctoberNovember.

From Table $\mathrm{V}$ it will be seen that there is some slight relationship of yaws incidence with an average monthly rainfall over 6 in. $(15 \mathrm{~cm}$.) and an average relative humidity at 14.30 hours over $50 \%$. An analysis of the community activities of the Lango, however, suggests that the attendance peaks under consideration coincide with the slackest periods of local husbandry-between the planting and harvesting of early and late crops.

\section{Out-patient Attendances, Kampala}

From the out-patient record cards at Mulago Hospital, Kampala, for attendances during 1933 and 1934, notes were made in 190 cases diagnosed as secondary syphilis. This is 
only a small proportion of the total attendance for that disease, but these records, mostly of Ganda patients, were chosen for their relative completeness. In 173 of these 190 cases (all young adult males) the serum Kahn was positive or spirochaetes were found. In 7 the serum Kahn was negative. Penile sores were present in 60 cases; 41 admitted and 6 denied having had any penile lesions. Among these 190 cases the following frequency of lesions was recorded: condylomata, 91 ; " secondary rashes," 21 ; macules, 20 ; papules, 14 ; maculo-papules, 9 ; circinate lesions on scrotum, 8; buccal mucous membrane lesions, 8 ; papulo-squamous, 3 ; squamous, 2 ; circinate, 2 . The condylomata were described as scrotal, perineal, and anal. No mention was made of any framboesiform lesions. At Lira the atypical secondary yaws lesions, and genital lesions, in the absence of typical lesions were infrequent. Loewenthal (1939) reported syphilitic aortitis and aneurysm, meningo-vascular lesions, choroiditis, and gummatous iritis in patients at Mulago, but stated that visceral gummata were rare. Such lesions were not seen among the Lango.

\section{Serological Surveys}

Sera collected in January, 1939, from 100 consecutive male Lango prisoners, aged 18 to 35 years, in the Erute (Lira) Gaol gave the following $\mathrm{Kahn}$ reactions:,$++++ 46 ;+++, 21$; ,$++ 14 ;+, 2 ; \pm, 7$; and,- 10 . If reactions of,+ \pm , and - are regarded as negative, then 81 were positive. The ages of these subjects were: $18-20$ years, $32 ; 21-25,36$; $26-30,23 ; 31-35,9$. Other findings in this group and in 130 station labourers are given in Table VI.

TABLE VI.-Clinical Findings in Two Groups of Adult Lango Males at Lira

\begin{tabular}{|c|c|c|c|c|}
\hline & 100 Prisoners & 130 Station Labourers \\
\hline $\begin{array}{l}\text { History of havin } \\
\text { Scars of previou } \\
\text { Enlarged epitroc } \\
\text { Bone changes } \\
\text { Palmar changes } \\
\text { Plantar changes } \\
\text { Bone pain }\end{array}$ & $\begin{array}{l}\text { g h } \\
\text { s se } \\
\text { hle } \\
\ldots \\
\ldots \\
\ldots \\
\ldots\end{array}$ & 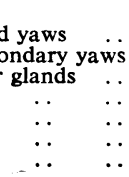 & $\begin{array}{l}\% \\
94 \\
78 \\
72 \\
68 \\
51 \\
61 \\
49\end{array}$ & $\begin{array}{l}\% \\
90 \\
79 \\
69 \\
62 \\
60 \\
73 \\
41\end{array}$ \\
\hline
\end{tabular}

One case each of dorsal ganglion of the wrist, Dupuytrenlike contractures of the fingers, and aortic systolic murmur was seen among prisoners under 30 years of age; the sera from these were $\mathrm{Kahn}++++$. Among the labourers were 4 cases with ganglion and 12 with Dupuytren-like contractures. Bone changes consisted mainly of bowing, thickening, or irregularity of tibiae. Palmar and plantar changes comprised thickening, localized or generalized erosion, fissuring, pitting, and laminar desquamation.

Among the prisoners no statistical association was found between any of the items in Table VI and the reaction of the serum Kahn. The six prisoners who denied having had yaws were under 25 years of age ; the serum from two was Kahn ++++ , from another two it was Kahn +++ , and from the remaining two Kahn -. The last two subjects were 20 years of age, both complained of bone pain, one had enlarged epitrochlear glands, and the other had indefinite minor plantar changes. Of 120 male Lango prisoners in the Erute (Lira) Gaol, in October, 1938, 8 denied having had yaws. Their ages ranged from 17 to 33 . Sera from four were Wassermann ++++ and Kahn ++++ , those from the remaining four were Wassermann - ; from one of these it was Kahn +, from another Kahn \pm , and from the remaining two Kahn -.

\section{Summary and Conclusions}

In 1931 a survey showed that $3.9 \%$ of 24,249 children under 15 years of age were suffering from secondary yaws.

At Lira, in a "yaws area," yaws was a frequently diagnosed disease $(20 \%$ of 14,707$)$ and was 19 times as frequent as syphilis. At Masaka, in a "syphilis area," syphilis was a frequently diagnosed disease $(17 \%$ of 16,207$)$ and was 11 times as frequent as yaws. At each locality coughs, colds, and traumatic lesions were the most frequent diagnoses. Malaria was probably of nearly universal incidence in both localities. At Lira females were proportionately more numerous among the yaws cases than among the total attendances. A quarter of the yaws cases were under 10 years of age. There was a smaller proportionate excess of females among the syphilis cases at Masaka as compared with the total attendances. Syphilis cases at Masaka were older compared with the age distribution of the other attendances.

In 1939,81 of 100 consecutive male Lango prisoners, aged 18-35, had positive Kahn reactions. Of the six of this series who denied having had yaws, only two had completely negative Kahn and Wassermann reactions in their sera.

It may be concluded that the incidence of yaws in Lango was high, and that probably very few adults died without having contracted the disease. On the other hand, in Lango the incidence of venereal disease was very low.

The material for this paper was obtained during 1937-40 while holding a Senior Fellowship in Tropical Medicine of the Medical Research Council. I am indebted for much help received to Dr. W. H. Kauntze, then D.M.S., Uganda, and his medical officers All serological tests were carried out by the staff of the pathological laboratory at Mulago Hospital. Dr. W. J. Martin, of the Statistical Department of the Medical Research Council, has kindly carried out the statistical analyses.

REFERENCE

Loewenthal, L. J. A. (1939), Urol. cutan. Rev., 43, 182.

\section{EFFECT. OF ORGANIC MERCURIAL PREPARATIONS ON DISEASES OF THE SKIN}

BY

\section{E. A. J. BYRNE, M.D., M.R.C.P. \\ Lately Medical Specialist, R.A.M.C.}

A preliminary report on organo-mercurial treatment of the dermatomycoses and of infected skin lesions, including " jungle sores," was published in the Indian Medical Gazette in August, 1944 (Byrne and Croxon). This present report is an amplification, and is based on the treatment of 500 cases of skin lesions in the Tropics with organo-mercurial compounds. Three preparations were used-phenyl mercuric chloride, acetate, and benzoate; they will be referred to subsequently as P.M.C., P.M.A., and P.M.B.

The toxic action of mercury on bacteria depends on the free concentration of $\mathrm{Hg}$ ions in solution (Paul and Prall, 1907), and it has been shown that the $\mathrm{Hg}$ cation is the most effective of the heavy metal cations (Woodruff and Bunzel, 1909; Winslow and Hotchkiss, 1922); but though the inorganic salts of mercury have a powerful action in vitro their bactericidal effect is greatly diminished in vivo, especially in the presence of organic matter. Chick and Martin (1908) consider that this is due to the fact that the $\mathrm{Hg}$ cation combines with protein to form an insoluble albuminate, hence the concentration of free ions is greatly diminished. The same workers reported that the addition of $3 \%$ of faeces to a solution reduced the activity of mercuric chloride by $90 \%$. The activity of certain organo-mercurials under these conditions is reduced only by $20-25 \%$, for it appears that the formation of an insoluble albuminate does not obtain to any marked degree with drugs of this group. It therefore follows that in the presence of organic protein matter the organo-mercurials possess a far greater bactericidal effect than do the inorganic salts of mercury.

An exceptional toxicity towards all forms of life is exhibited by those compounds of mercury which structurally are the most simple, and this lethal action is markedly selective in highly organized animals: the effect is determined largely by the character of the hydrocarbon radicle-aromatic or aliphaticassociated with the mercury atom, aliphatic compounds being particularly virulent. On the other hand, aromatic derivatives have a relatively low local and systemic toxicity, and, provided the hydrocarbon is an unsubstituted phenyl radicle $\left(\mathrm{C}_{6} \mathrm{H}_{5}\right)$, a very high bactericidal potency.

It is important to record in connexion with specific action that the aliphatic organo-mercurials exemplified by mercury dimethyl and diethyl- $\left(\mathrm{CH}_{3}\right)_{2} \mathrm{Hg}$ and $\left(\mathrm{C}_{2} \mathrm{H}_{5}\right)_{2} \mathrm{Hg}$-and derivatives thereof, such as the chloride $\left(\mathrm{CH}_{3} \mathrm{HgCl}\right)$ and nitrate $\left(\mathrm{CH}_{3} \mathrm{HgNO}_{3}\right)$, have a specific effect on the C.N.S., causing rapid degenerative lesions in cerebral and cerebellar areas. These compounds are most interesting in human toxicology, 